\title{
MORALITAS ANAK DAN KAITANNYA DENGAN URGENSI PENDIDIKAN ISLAM
}

\author{
Oleh: Syarifuddin Ondeng
}

\begin{abstract}
The morality issues always colored human life from the changing of time. The basic principle of morality is identically with character or ethics. These terms have similar meaning, those are; habit, character, and disposition. The morality always refers to good and bad aspect of someone, whether he is an adult or a child. In Islam, child's morality does not only inform good aspect, but also bad aspect in his behavior. Thus, the important thing is how to show Islamic education toward the child. Therefore, he/she can apply goodness in his life, so that he gets benefit for himself. In spite of the consequence of child's morality and the urgent of Islamic education is very interesting to be studied accurately and deeply.
\end{abstract}

KEYWORDS: Moralitas, anak, pendidikan Islam

ALQURAN sangat menekankan pemeliharaan dan pengasuhan anak, serta jaminan terhadap kehidupan mereka. Orang-orang Arab sebelum Islam, membunuh anak-anak mereka karena tidak mampu memenuhi kebutuhannya, dan dalam bentuk khusus mereka menguburkan anak wanita secara hidup-hidup. Selanjutnya Islam datang dengan membawa petunjuk agar memelihara jiwa anak-anak dan melarang menguburkan anak wanita hidup-hidup.

Dalam perspektif Islam, anak merupakan nikmat yang harus disyukuri, karena anak merupakan penghibur hati bagi kedua orangtua, sebagaimana dalam Q.S. al-Furqan (25): 74 Allah berfirman:

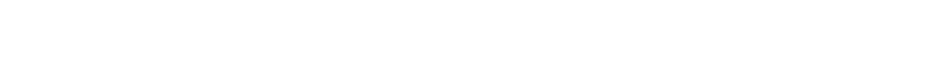

Dan orang-orang yang berkata: "Ya Tuhan kami, anugrahkanlah kepada

kami isteri-isteri kami dan keturunan kami sebagai penghibur hati (kami)

dan jadikanlah kami imam bagi orang-orang yang bertaqwa. ${ }^{1}$

Ayat di atas menerangkan bahwa anak sebagai keturunan menjadi salah satu motivasi atas ketenteraman suasana keluarga, karena ia sebagai penghibur hati. Tentu saja, hanya anak yang shalehlah sebagai 
sebagai penghibur hati, sementara anak yang durhaka tidak termasuk sebagai anak yang mampu menghibur hati. Karena itu, dari ayat ini pula dapat dipahami bahwa moralitas anak seharusnya dibina berdasarkan konsep pendidikan Islam. Selanjutnya, bilamana bertolak dari ajaran agama Islam, maka akan didapati kurang lebih 53 sub bahasan dalam Alquran yang terkait dengan pendidikan Islam terhadap moralitas anak. $^{2}$

Berdasarkan latar belakang di atas, maka dapat dirumuskan bahwa moralitas anak dan kaitannya dengan urgensi pendidikan Islam sangat menarik untuk dikaji, dengan permasalahan, bagaimana konsepsi moralitas anak; bagaimana pandangan pendidikan Islam terhadap moralitas anak; bagaimana tujuan pendidikan Islam dalam pembentukan moralitas anak dan faktor-faktor yang mempengaruhinya?

\section{KONSEPSI TENTANG MORALITAS ANAK}

Perkataan "moral" berasal dari bahasa latin, yakni "mores" kata jamak dari "mos" yang berarti adat kebiasaan atau susila. ${ }^{3}$ Dengan demikian, moralitas merupakan suatu sikap yang sesuai dengan ide-ide umum yang diterima tentang tindakan manusia, mana yang baik dan wajar. Jadi, moralitas dapat diumpamakan sebagai cetakan dengan batas-batas yang jelas yang terpatri pada sikap dan perilaku seseorang.

Ukuran peradaban suatu bangsa dapat diukur dari sejauhmana tingkat moralitas atau akhlak penduduknya. Moralitas bukanlah sekedar menginformasikan mana yang baik dan mana yang buruk. Namun yang terpenting adalah bagaimana mengaplikasikannya dalam kehidupan dalam bentuk kebaikan-kebaikan yang mendatangkan manfaat bagi sesama manusia.

Antara moral dan akhlak terdapat persamaan dan perbedaan. Persamaannya adalah, keduanya membahas tentang baik dan buruk dari tingkah laku manusia. Sedang perbedaannya adalah, apabila tingkah laku manusia dilihat dari aspek umum dan pemahaman Barat, maka ia cenderung disebut moral, sedang apabila dilihat dari ajaran Islam, maka ia disebut akhlak, baik yang termasuk akhlak mulia ataupun akhlak yang tercela. Penggunaan istilah moral dan akhlak dalam skripsi ini terkadang digunakan silih berganti ataupun bersamaan karena adanya persamaan yang signifikan.

Apabila dikaitkan dengan pendidikan anak dalam rumah tangga, maka hal itu bukanlah berpangkal tolak dari kesadaran dan pengertian yang lahir dari pengetahuan mendidik, melainkan karena secara kodrati suasana dan struktur yang memberikan kemungkinan alami mem- 
bangun situasi pendidikan. Situasi pendidikan itu terwujud berkat adanya pergaulan dan hubungan timbal balik antara orang tua dan anak. Tanggung jawab pendidikan secara mendasar terpikul kepada orang tua, apakah tanggung jawab itu diakuinya secara sadar atau tidak, diterima sepenuh hati atau tidak, hal itu merupakan fithrah yang telah dikodratkan Allah awt kepada setiap orang tua. ${ }^{4}$

Sehubungan dengan itu, maka moralitas anak yang dimaksudkan di sini adalah sikap keimanan sebagai dasar ajaran Islam bagi anak-anak dalam wujud tingkah laku yang benar dalam menegakkan perintah agama sebagaimana ditegaskan dalam hadis Rasulullah Saw yang diriwayatkan oleh Dawud berikut ini:

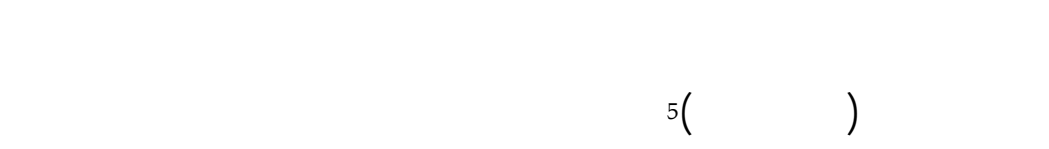

Hadis dari Abu Huraerah beliau berkata bahwa Rasulullah saw bersabda : orang mukmin yang paling sempurna imannya ialah yang terbaik akhlaknya.

Hadis di atas menunjukkan suatu sikap agar umat Muslim hendaknya senantiasa berbudi pekerti luhur. Karena yang demikian itulah yang terbaik untuk membina moral masyarakat.

Karena itu, moralitas anak termasuk gerakan dalam jiwanya yang menjadi sumber perbuatannya yang bersifat alternatif, baik atau buruk; bagus atau jelek sesuai dengan pengaruh pendidikan yang diberikan kepadanya.

\section{PANDANGAN PENDIDIKAN ISLAM TERHADAP MORALITAS ANAK}

Pendidikan Islam adalah usaha yang dilakukan secara sadar dengan membimbing, mengasuh anak atau peserta didik agar dapat menyakini, memahami, menghayati, dan mengamalkan ajaran-ajaran Islam. ${ }^{6}$

Jika masalah moralitas anak dikaitkan dengan pendidikan Islam, maka salah satu hal penting yang harus dicermati etika atau moral anak adalah perasaannya mengenai akhlak. Dari sini kemudian timbul persepsi bahwa, ada anak yang bermoral dan ada pula anak yang tidak bermoral. Dari manakah timbulnya persepsi ini dan bagaimana hati nurani dapat mengenal baik dan buruk, antara yang hak dengan yang batil.

Seseorang melihat misalnya, suatu perbuatan dinyatakan baik dan benar pada suatu masa atau bangsa tertentu, sedang perbuatan itu dianggap buruk atau salah pada masa lain atau pada bangsa lainnya. 
Untuk menjawab permasalahan ini, oleh para pajar terbagi menjadi dua golongan, yakni;

1. Golongan pertama berpendapat bahwa tiap-tiap manusia mempunyai kekuatan instinct yang dapat membedakan antara hak dan batil, baik dan buruk; berakhlak atau tidak berakhlak. Kekuatan ini terkadang berbeda sedikit antara satu orang dengan orang lain, karena perbedaan masa dan lingkungan, tetapi tetap berakar pada setiap manusia. Maka tiap-tiap manusia mempunyai semacam ilham yang dapat mengenal nilai sesuatu akan baik dan buruknya.

2. Golongan kedua berpendapat, bahwa pengertian tentang baik dan buruk sama halnya dengan pengertian tentang sesuatu hal yang lainnya, ia tergantung pada pengalaman. Ia tumbuh seiring dengan pertumbuhan zaman dan kecerdasan pikiran. Mereka berpendapat manusia tidak memiliki instinct untuk mengetahui baik dan buruk, tetapi pengalamanlah yang telah memberi ketentuan hukum baik pada setiap perbuatan dan hukum buruk pada sebagian yang lain.

Seseorang yang berbuat perbuatan dengan melihat akibat perbuatannya, maka ia mengetahui hasil yang baik dari setiap perbuatanperbuatan itu, sehingga ia berkeyakinan akan kebaikannya; demikian pula ia melihat akibat-akibat buruk dari sebagian perbuatan-perbuatan itu, sehingga ia memberi hukum akan keburukannya. Sebenarnya kekuatan moral yang dapat mengenal baik dan buruk itu tidak lain adalah pengalaman. ${ }^{7}$

Kaitannya dengan itu, maka pandangan pendidikan Islam terhadap moralitas dan bebebarapa aspek yang terkait dengannya, kita bisa dapatkan antara lain pada Q.S. Luqman (31): 13-19 dengan penjelasan bahwa dari tujuh ayat dalam surah Luqman tersebut sarat dengan pesan-pesan pendidikan moral terhadap anak, yakni;

1. Ayat 13, tentang moral kepada Sang Khalik, yakni pendidikan akidah ketauhidan.

2. Ayat 14 , adalah sikap moral terhadap orang yang paling berjasa bagi kita, dalam hal ini kedua orang tua.

3. Ayat 15 , sebuah isyarat bahwa kemusyrikan adalah hal yang sangat tercela, bahkan termasuk dosa yang paling besar, sehingga siapapun bahkan kedua orang tua sekalipun yang mengajak kepada kemusyrikan, wajib ditentang.

4. Ayat 16 ditegaskan agar seorang anak haruslah selalu waspada dan hati-hati dalam kehidupan, sebab setiap perbuatan, walau sekecil apapun akan dimintai pertanggung jawaban dari Allah swt.

5. Ayat 17, adalah perintah harmonisasi antara hubungan vertikal 
manusia dengan Tuhan melalui perintah menegakkan shalat dengan hubungan horinsontal dengan sesama manusia melalui amar ma'ruf nahy munkar dan keharusan berlapang dada dengan kesabaran terhadap cobaan yang menimpa.

6. Ayat 18, larangan bersikap sombong karena kesombongan dan keangkuhan adalah salah satu sikap jelek yang dibenci Allah swt.

7. Ayat 19 , adalah perintah untuk bersikap sederhana dalam berbicara dan bertindak, karena kesederhanaan adalah sikap moral yang baik dan merupakan salah satu ciri orang yang beriman, sebagaimana Rasulullah saw menjadi teladan utama dan paling mulia akhlaknya yang ditegaskan oleh Allah swt dalam Q.S. al-Ahzab (33): 21 dan Q.S. al-Qalam (68): 4

TUJUAN PENDIDIKAN ISLAM DALAM PEMBENTUKAN MORALITAS ANAK DAN FAKTOR-FAKTOR YANG MEMPENGARUHINYA

Tujuan pembentukan sikap moral merupakan bagian yang sangat urgen dalam pendidikan Islam. Oleh karena itu, konsep pendidikan Islam terhadap moralitas anak adalah bimbingan jasmani dan rohani berdasarkan hukum-hukum agama Islam menuju kepada terbentuknya moralitas utama menurut ukuran-ukuran Islam.

Moralitas utama yang dimaksudkan di atas adalah kepribadian anak yang berasaskan nilai-nilai agama Islam, memilih, memutuskan dan berbuat serta bertanggung jawab berdasarkan nilai-nilai Islam. Karena itulah, maka Ahmad D. Marimba memberi batasan tentang tujuan pendidikan Islam ialah;

Bimbingan atau pimpinan secara sadar oleh si pendidik terhadap perkembangan jasmani dan rohani si terdidik menuju terbentuknya kepribadian yang utama. ${ }^{8}$

Menurut Muhammad Athiyah al-Abrasyi bahwa tujuan umum pendidikan Islam yang paling utama dan pertama adalah untuk membantu pembentukan akhlak yang mulia. ${ }^{9}$ Jadi, secara garis besar tujuan pembentukan sikap moral identik dengan tujuan pendidikan Islam.

Namun secara spesifik, tujuan pembentukan sikap moral bagi anak adalah agar anak dapat mengetahui perbedaan-perbedaan perangai manusia yang baik maupun yang jahat, agar anak dapat lebih tertarik mengikuti perangai-perangai yang baik dengan melihat contoh teladan dari lingkungannya, utamanya orang tuanya dan selanjutnya anak dapat menjauhi perangai-perangai yang jahat karena akibat-akibat buruk yang ditimbulkannya, sehingga anak sebagai calon manusia dewasa dapat 
menciptakan suasana aman, damai dan sejahtera dalam bingkai ukhuwah islamiyyah dan ketakwaan kepada Allah swt.

Ketaqwaan merupakan benih pembentukan fungsi rohani yang akan memberikan pengaruh terhadap moralitas anak, karena dengan taqwa tersebut di dalamnya terdapat nilai-nilai moral yang luhur. ${ }^{10}$ Sebagai hamba Allah, ia mengambang tugas sebagai khalifah atau wakil Allah di atas bumi yang harus melaksanakan segala peraruran-peraturan Allah, membina kemakmuran, membangun peradaban dan kebudayaan sesuai dengan petunjuk-petunjuk Allah. Dengan demikian, Islam mem-berikan sumber inspirasi dan motivasi dalam berbuat karya secara kreatif. Karena itu, internaslisasi nilai-nilai agama melalui pendidikan Islam menjadi sesuatu hal yang mendasar dalam pembentukan moralitas anak.

Pada tabiatnya, sejak kelahiran anak ia telah membawa suatu kecenderungan beragama yang disebut fitrah, sebagaima dalam Q.S. alRum (30): 30 yang telah dipaparkan pada bab sebelumnya.

Term $\mid$ فرة (fitrah Allah) pada ayat tersebut mengandung interpretasi bahwa setiap anak yang lahir telah mempunyai naluri beragama, yaitu agama tauhid. ${ }^{11}$ Potensi fitrah Allah pada diri setiap anak menyebabkannya ia selalu mencari yang dipandang sebagai realitas mutlak (ultimate reality), dengan cara mengekspresikannya dalam bentuk sikap, cara berpikir dan bertingkah laku.

Karena itu, anak yang baru lahir dalam keadaan suci tersebut pada masa tahapan berikutnya harus dapat diarahkan melalui proses pendidikan dengan memandang fitrah sebagai obyek yang harus dikembangkan dan disempurnakan, dengan cara membimbing dan mengasuhnya agar dapat memahami, menghayati dan mengamalkan ajaran-ajaran keagamaan (Islam) secara universal.

Fitrah dalam hal ini kesucian moralitas yang dibawa sejak lahir, tentu saja pada tahapan-tahapan berikutnya akan mengalami tingkatantingkatan yang bervariasi, sesuai dinamika dan faktor-faktor yang mempengaruhinya. Faktor pertama yang mempengaruhi kesucian moralitas anak adalah lingkungan keluarga, sebagai unit pertama dan institusi pertama anak dipelihara, dibesarkan dan dididik.

Lingkungan keluarga di sini memberikan peranan yang sangat berarti dalam proses pembentukan moralitas anak. Sebab di lingkungan inilah anak menerima sejumlah nilai dan norma yang ditanamkan sejak awal kepadanya. Sejalan dengan kepentingan dan masa depan anak-anak, maka orang tua menyekolahkan anak-anak mereka dan secara kelembagaan sekolah di sini sebagai faktor kedua yang dapat memberikan pengaruh dalam membentuk moralitas. 
Namun besar kecil pengaruh yang dimaksud sangat tergantung berbagai faktor yang dapat memotivasi anak untuk membentuk moralitasnya. Hal ini disebabkan perkembangan keagamaan anak, juga dimotivasi oleh perkembangan bakat dan kepribadiannya.

Lingkungan sekolah dalam kaitannya dengan pembentukan moralitas pada anak, antara lain sebagai lanjutan pendidikan agama di lingkungan keluarga atau membentuk jiwa keagamaan pada diri anak yang tidak menerima pendidikan agama dalam keluarga. Dalam perspektif Islam, fungsi sekolah sebagai media realisasi pendidikan berdasarkan tujuan pemikiran, aqidah dan syariah dalam upaya penghambaan diri terhadap Allah dan mentauhidkan-Nya sehingga manusia terhindar dari penyimpangan fitrahnya. Artinya, moralitas anak diarahkan agar tetap mempertahankan naluri keagamaan tidak keluar dari bingkai normativisme Islam.

Pada tahapan selanjutnya, perkembangan fisik anak dapat dilihat sebagai integritas proses-proses sosialisasi. Di antara tahapan perkembangan fisik anak yang paling kritis adalah ketika memasuki masa puberitas. Pada tahapan ini, moralitas dipengaruhi oleh berbagai faktor, baik yang sifatnya negatif maupun yang positif. Hanya saja, dalam pandangan Syahruddin, pada masa ini (tahapan puberitas) anak-anak seringkali memperlihatkan moralitas yang negatif, berupa tindakantindakan antara lain; perkelahian, mabuk-mabukan, morfinis. ${ }^{12}$ Jadi, pada umumnya anak pada masa ini mengalami kemerosotan moral yang disertai sikap menjahui nilai-nilai agama.

Yang paling penting adalah untuk memandang anak dari awal mula sebagai interaksi yang serius yang secara aktif ikut memberikan bentuk pada perkembangannya, anak mempunyai sifat ingin bersatu dengan lingkungan sosial, maka lingkungan sosial harus memberikan kesempatan kepada anak untuk dapat memenuhi dorongan sosial itu. Oleh karena itu, jika anak berada pada tahapan puberitas mengalami pertentangan bathin yang paling memuncak dalam kehidupannya di sinilah perlunya semua pihak khususnya orang tua membimbing dan menanamkan nilai-nilai moralitas terhadap anak-anak mereka.

\section{PENUTUP}

Berdasar dari uraian-uraian sebelumnya, maka dapat disimpulkan bahwa moralitas anak dalam Islam merupakan salah satu aspek yang sangat esensial dalam hidup dan kehidupan. Sehingga, pembentukan moralitas anak sesuai ajaran Islam menjadi tugas utama dunia pendidikan Islam. 
Pendidikan Islam sebagai usaha pembimbingan anak dalam upaya pembentukan moralitas terkonsep dalam Q.S. Luqman (31): 13-19. Dalam sederetan ayat ini, sarat dengan pesan-pesan pendidikan moral terhadap anak-anak yang pada intinya adalah beriman dan bertakwa, serta berbudi pekerti luhur.

Akhirnya, dapat dirumuskan bahwa pembentukan sikap moralitas anak seperti yang digambarkan di atas, merupakan bagian yang sangat urgen dalam pendidikan Islam. Tujuannya adalah agar anak dapat lebih tertarik mengikuti perangai-perangai yang baik dengan melihat contoh teladan dari lingkungan keluarganya, sekolahnya dan masyarakatnya.

\section{CATATAN AKHIR:}

1. Departemen Agama RI, Al-Qur'an dan Terjemahnya, Jakarta: Proyek Pengadaan Kitab Suci al-Qur'an, 1992, h. 569.

2. Lihat Choirduddin Hadhiri. SP, Klasifikasi kandungan Al-Qur'an, cet. I, Jakarta: Gema Insani Press, 1993, h. xvi-xvii.

3. Tim Penyusun Kamus Pusat Pembinaan dan Pengembangan Bahasa Depdikbud, Kamus Besar Bahasa Indonesia, cet. X, Jakarta: Balai Pustaka, 1999, h. 456.

4. Zakiah Daradjat, Ilmu Pendidikan Islam, cet. II, Jakarta: Bumi Aksara, 1992, h. 16.

5. Lihat Abu Dawud Sulaiman bin al-Asy'asy al-Sijistani, Sunan Abu Dawud, juz II, Suriah: Dar al-Hadits, t.th, h. 537.

6. Mappanganro, Implementasi Pendidikan Islam di Sekolah, cet. I, Ujung Pandang: Yayasan Ahkam, 1996, h. 10. Pengertian pendidikan Islam yang sepadan dengan defenisi yang dikemukakan di atas, dapat pula dilihat dalam Zakiah Daradjat, Ilmu Pendidikan Islam, h. 27; lihat juga M. Arifin, Ilmu Pendidikan Islam, Jakarta: Bumi Aksara, 1991, h. 10. Untuk lebih jelasnya, lihat Wan Moh. Nor Wan Daud, The Educational Philosophi and Practice of Syed Muhammad Naquib al-Attās, diterjemahkan oleh Hamid Fahmi, dkk. dengan judul: Filsafat dan Praktik Pendidikan Islam Syed M. Naquib al-Attas, cet. I, Bandung: 1998, h. 180-182.

7. Ahmad Amin, Etika: Ilmu Akhlak, cet. VII, Jakarta: Bulan Bintang, 1993, h. 86.

8. Ahmad D. Marimba, Pengantar Filsafat Pendidikan Islam, cet. VIII, Bandung: PT. AlMa’arif, 1989, h. 19.

9. Umar Muhammad al-Taumiy al-Syaibani, Falsafah al-Tarbiyah al-Islamiyyah diterjemahkan oleh Hasan Langgulung dengan judul: Falsafah Pendidikan Islam, cet. I, Jakarta: Bulan Bintang, 1979, h. 416-417.

10. Abdul Rahman Barakatuh, "Internalisasi Nilai Agama; Suatu Proses Pembentukan Manusia dalam Rangka Pembangunan Bangsa, dalam Warta Alauddin No. 76, Ujung Pandang: IAIN Alauddin, 1996, h. 122.

11. Lihat interpretasi yang dikemukakan oleh al-Raghib al-Ashfahani, Mufradat Alfadz alQur'an, cet. I, Beirut: Dar al-Syamiyah, 1992, h. 640.

12. Syahruddin, "Perilaku Anak pada Usia Puberitas terhadap Nilai-nilai Agama”, dalam Warta Alauddin No. 65, Ujung Pandang: IAIN Alauddin, 1993, h. 134. 


\section{DAFTAR PUSTAKA:}

Amin, Ahmad, Etika: Ilmu Akhlak, cet. VII, Jakarta: Bulan Bintang, 1993.

Arifin, M., Ilmu Pendidikan Islam, Jakarta: Bumi Aksara, 1991.

Al-Ashfahani, al-Raghib, Mufradat Alfadz al-Qur'an, cet. I, Beirut: Dar al-Syamiyah, 1992.

Barakatuh, Abdul Rahman, "Internalisasi Nilai Agama; Suatu Proses pembentukan Manusia dalam Rangka Pembangunan Bangsa”, dalam Warta Alauddin No. 76, Ujung Pandang: IAIN Alauddin, 1996.

Daradjat, Zakiah, Ilmu Pendidikan Islam, cet. II, Jakarta: Bumi Aksara, 1992.

Daud, Wan Moh. Nor Wan, The Educational Philosophi and Practice of Syed Muhammad Naquib al-Attās, diterjemahkan oleh Hamid Fahmi, dkk. dengan judul Filsafat dan Praktik Pendidikan Islam Syed M. Naquib al-Attas, cet. I, Bandung: 1998.

Departemen Agama RI, Al-Qur'an dan Terjemahnya, Jakarta: Proyek Pengadaan Kitab Suci al-Qur'an, 1992.

Hadhiri, Choirduddin, Klasifikasi Kandungan Al-Qur'an, cet. I, Jakarta: Gema Insani Press, 1993.

Mappanganro, Implementasi Pendidikan Islam di Sekolah, cet. I, Ujung Pandang: Yayasan Ahkam, 1996.

Marimba, Ahmad D., Pengantar Filsafat Pendidikan Islam, cet. VIII, Bandung: PT. AlMa'arif, 1989.

Al-Sijistani, Abu Dawud Sulaiman bin al-Asy'asy, Sunan Abu Dawud, juz II, Suriah: Dar al-Hadits, t.th.

Syahruddin, "Perilaku Anak pada Usia Puberitas terhadap Nilai-nilai Agama”, dalam Warta Alauddin No. 65, Ujung Pandang: IAIN Alauddin, 1993.

Al-Syaibani, Umar Muhammad al-Taumiy, Falsafah al-Tarbiyah al-Islamiyyah diterjemahkan oleh Hasan Langgulung dengan judul: Falsafah Pendidikan Islam, cet. I, Jakarta: Bulan Bintang, 1979.

Tim Penyusun Kamus Pusat Pembinaan dan Pengembangan Bahasa Depdikbud, Kamus Besar Bahasa Indonesia, cet. X, Jakarta: Balai Pustaka, 1999. 